\title{
PECULIARITIES OF PERCEPTION OF NATIONALISM AT THE REGIONAL LEVEL (BASED ON THE MATERIALS OF EMPIRICAL RESEARCH IN THE SARATOV REGION)
}

\author{
Aleksandr A. Vilkov \\ Doctor of Sciences (Politics), Professor, Head of Department of Political Sciences, \\ National Research Saratov State University \\ vil57@yandex.ru \\ Astrakhanskaya St., 83, 410012 Saratov, Russian Federation
}

\section{Vyacheslav A. Kalinin}

Postgraduate Student, Department of Political Sciences, National Research Saratov State University slaffka.kalinin@yandex.ru Astrakhanskaya St., 83, 410012 Saratov, Russian Federation

Abstract. The article is devoted to the analysis of the data obtained through the mass questionnaire survey of residents of the Saratov region in 2015. The authors found the perception of nationalism by citizens, the link between political views of the respondents, and their political engagement, and political participation, as well as the influence of political parties on the expression of nationalist feelings in society.

Special attention is paid to the spread of nationalist attitudes among different population groups in connection with: the negative attitude of some foreign countries to the actions of Russia in Ukraine and the reunification of the Crimea with Russia; with the aggravation of the economic crisis, the sanctions imposed by the European Union and the United States that led to such consequence as a decrease in the standard of living of the majority of Russian citizens; with the continuing influx of migrants, which increases the likelihood of xenophobia and radicalism.

The authors conclude that in the minds of Russian citizens the ambiguous interpretation of nationalism dominates. On the one hand, nationalism is interpreted as a negative and dangerous phenomenon associated with the superiority of one ethnic group over the others. On the other hand, it is understood as the strengthening of state nationalism, largely defined by the patriotic feelings of love for their country in a globalized world, the desire to reduce the sovereignty, Russia's active position in the fight against ISIL. There is a trend of decrease of ethnic nationalist and xenophobic attitudes in the face of external challenges and threats. However, this does not mean conscious establishment of the values of tolerance in the political culture of those groups of Russians who tend to manifest xenophobia. In this case there is a situational transferring of one's rejection of the "other" to the external environment.

Key words: nationalism, political party, ideology, empirical research, political participation, Russia, Saratov region.

\section{ОСОБЕННОСТИ ВОСПРИЯТИЯ НАЦИОНАЛИЗМА НА РЕГИОНАЛЬНОМ УРОВНЕ (ПО МАТЕРИАЛАМ ЭМПИРИЧЕСКИХ ИССЛЕДОВАНИЙ В САРАТОВСКОЙ ОБЛАСТИ)}

\section{Александр Алексеевич Вилков}

Доктор политических наук, профессор, заведующий кафедрой политических наук, Саратовский государственный университет им. Н.Г. Чернышевского 
vil57@yandex.ru

ул. Астраханская, 83, 410012 г. Саратов, Российская Федерация

\section{Вячеслав Андреевич Калинин}

Аспирант кафедры политических наук,

Саратовский государственный университет им. Н.Г. Чернышевского

slaffka.kalinin@yandex.ru

ул. Астраханская, 83, 410012 г. Саратов, Российская Федерация

Аннотация. Статья посвящена анализу данных, полученных на основе проведенного в 2015 г. массового анкетирования жителей Саратовской области. Авторы выявили восприятие гражданами национализма, взаимосвязь между политическими взглядами респондентов, их политизированностью и политическим участием, а также влияние деятельности политических партий на проявление националистических настроений в обществе.

Особое внимание в статье обращено на распространение националистических взглядов среди различных групп населения в связи с негативным отношением ряда зарубежных стран к действиям России в Украине и воссоединению Крыма с РФ; обострением последствий экономического кризиса, санкционных мер со стороны стран Европейского Союза и США и, как следствие, снижением жизненного уровня большинства российских граждан; продолжающимся притоком мигрантов, что повышает вероятность проявления ксенофобии и радикализма.

Авторы приходят к выводу о том, что в сознании российских граждан доминирует двоякое толкование национализма: во-первых, как негативного и опасного явления, связанного с превосходством одного этноса над другими; во-вторых, как укрепления государственного национализма, во многом определяемого патриотическими чувствами любви к своей Родине в условиях глобализации мира, стремлению к снижению суверенитета, активной позицией России в борьбе против ИГИЛ. Отмечается тенденция к снижению этнонационалистических, ксенофобных настроений перед лицом внешних вызовов и угроз. Вместе с тем это не означает осознанное укоренение ценностей толерантности в политической культуре тех групп россиян, которые склонны к проявлению ксенофобии. В данном случае происходит ситуативное перенесение своего неприятия «другого» на внешнюю среду.

Ключевые слова: национализм, политическая партия, идеология, эмпирическое исследование, политическое участие, Россия, Саратовская область.

Проблема межнациональных и межэтнических отношений традиционно является одной из самых актуальных и социально значимых для России. В условиях обострения международной обстановки, нарастания последствий экономического кризиса и снижения жизненного уровня большинства российских граждан, с учетом продолжающегося притока мигрантов возрастает вероятность распространения радикальных националистических лозунгов и идей в обществе.

В этих рамках межнациональные отношения в России требуют постоянного мониторинга и системного анализа. Кроме того, на наш взгляд, целесообразно соотнести деятельность ведущих российских политических партий с проблематикой проявления националистических настроений в обществе. Представляется важным выявить как наличие и специфические характеристики национал-кон- сервативного дискурса в информационном пространстве российских партий, так и их отражение в общественном мнении.

В этой связи лабораторией социальнополитических исследований Саратовского государственного университета имени Н.Г. Чернышевского был проведен социологический опрос, целью которого стало выявление степени влияния деятельности и агитации политических партий на характер межэтнических отношений, изучение особенностей понимания гражданами национализма, его проявлений и последствий.

Саратовская область была выбрана потому, что представляет собой своеобразный региональный срез полиэтничного состава России в целом. Население Саратовской области представлено 135 этносами, русские составляют более 85 \% населения $[2$, с. 55]. В целом область относится к чис- 
лу регионов с достаточно высокой межэтнической напряженностью [1]. Об этом свидетельствуют периодически возникающие вспышки межэтнической агрессии. Например, общероссийскую известность получил «бунт» в городе Пугачев Саратовской области летом 2013 года.

Анкетирование проводилось с 20 октября по 25 ноября 2015 г. в городе Саратов и Саратовской области. Всего было опрошено 412 человек. Полученные данные были обработаны при помощи программы SPSS Statistics 17.0. Допущенные погрешности не превысили 2,7 \%. Анкета содержала 22 вопроса, 7 из которых были посвящены сбору статистической информации о респондентах. Понятия «нация» и «народ» были намеренно приравнены для упрощения понимания респондентами вопросов и вариантов ответа. Мы исходили из того, что в массовом восприятии данные понятия являются синонимами этнической идентификации (это фактически подтвердилось результатами исследования).

Стоит отметить настороженное отношение граждан к опросу, посвященному политике, несмотря на его анонимность; часто респонденты стремились выбрать «наименее радикальный» и «компромиссный» вариант ответа на вопрос, что отчасти может объясняться страхом перед ответственностью за оставленную информацию в анкете.

Гендерный состав опрошенных представлен 190 мужчинами (46,1%) и 217 женщинами $(52,7 \%), 5$ человек не указали свой пол $(1,2 \%)$.

Возрастной состав респондентов: от 18 до 21 года -48 человек $(11,7 \%)$, от 22 до 25 лет - 65 (15,8\%), от 26 до $30-46(11,2 \%)$, от 31 до 35 - 33 (8\%), от 36 до 45 лет - 57 $(13,8 \%)$, от 46 до 60 лет - 109 (26,5\%), старше 60 лет - 52 (12,6\%), не указавших свой возраст - $2(0,5 \%)$.

Образование респондентов: незаконченное среднее - 10 ответивших (2,4\%), среднее и среднее специальное - 116 (28,2 \%), незаконченное высшее - 52 (12,6 \%), высшее $222(53,9 \%)$, послевузовское - 8 (1,9\%), не указали образование - 4 (1\%).

Социальный статус граждан, принявших участие в опросе: работники внебюджетной сферы - 168 (40,8 \%), бюджетники - 72
(17,5 \%), пенсионеры - 66 (16\%), учащиеся / студенты - 55 (13,3 \%), безработные - 15 $(3,6$ \%), военнослужащие - 13 (3,2 \%), предприниматели / бизнесмены - 10 (2,4\%), госслужащие - 4 (1\%), прочие - 3 (0,6 \%), не указали - 6 (1,5\%).

Вопрос об уровне жизни граждан был ориентирован на выявление самооценки людей в силу затруднительности четкой социальной идентификации. Результаты оказались следующими: «хватает только на самое необходимое» - 196 ответов $(47,6$ \%), «могу позволить себе не только самое необходимое» 159 (38,6 \%), «еле свожу концы с концами» $40(9,7 \%)$, «ни в чем себе не отказываю» - 15 $(3,6 \%)$, не указали уровень жизни - 2 (0,5 \%).

Национальный состав респондентов: русские - 377 (91,5 \%), татары - 7 (1,7\%), украинцы - 5 ( $1,2 \%)$, евреи - $3(0,7 \%)$, мордва - 2 $(0,5 \%)$, прочие - $12(2,4 \%)$, не указавшие национальность - 6 (1,5\%).

Данные о проживании респондентов выглядят таким образом: жителей Саратова - 280 (68 \%), Пугачева - 16 (3,9 \%), Вольска и Энгельса - по 15 респондентов (по 3,6 \% соответственно), Балаково - 12 (2,9 \%), Балашова - 10 (2,4 \%), Ртищево - 9 (2,2 \%), Красного Кута - 6 (1,5 \%), Аткарска - 5 (1,2\%), Маркca - 4 (1\%), 3АТО Шиханы - $3(0,7 \%)$, Ершова - $2(0,5 \%)$, прочие - 24 (5,1 \%), не указали - 11 человек $(2,7 \%)$.

Результаты вопроса «Какую политическую партию современной России Вы поддерживаете?» (см. табл. 1) показывают, что со времени выборов в Государственную Думу 2011 г. партии в значительной степени утратили поддержку избирателей (прежде всего «Справедливая Россия» и ЛДПР), что отчасти объясняется снижением интенсивности агитации партий. Весьма велик процент респондентов, не поддержавших ни одну партию современной России и, вероятно, не желающих принимать в будущих выборах участия (до $40 \%$, что примерно равно неявке на выборы в Государственную Думу VI созыва). Женщины оказались более апатичны в поддержке тех или иных политических сил, однако почти половина из них поддерживала «Единую Россию» (в отличие лишь от трети мужчин); кроме того, женщины несколько чаще симпатизировали «Справедливой России». 
Мужчины, в свою очередь, незначительно чаще женщин поддерживали КПРФ, ЛДПР и непарламентские партии. В целом, респонденты не видели альтернатив существующей власти в лице «ЕР», за исключением КПРФ, которая, однако, имела дефицит поддержки в молодежной среде (основной электорат партии старше 46 лет). Прослеживалась нечеткая зависимость между повышением уровня образования респондентов и снижением поддержки партий. Лица, «еле сводящие концы с концами», преимущественно выступали «против всех», что говорит об их неготовности добиваться улучшения своего положения посредством выборов, в отличие от лиц, «ни в чем себе не отказывающих». Стоит обратить внимание, что ЛДПР поддерживали почти только русские, кроме того, респонденты в устной форме часто выражали негативное отношение к националистическим высказываниям лидеров этой партии. Существенных зависимостей между местом проживания и поддержкой определенных политических сил установить не удалось. Единственным городом, где поддержка КПРФ была несколько выше, чем «ЕР», оказался Энгельс.
Целью вопроса «В какой мере на Ваше мировоззрение и поведение оказывают влияние агитация партий, выступления их лидеров, программные положения?» (табл. 2) было выявление уровня вовлеченности граждан в политику. Большинство респондентов оказались безразличными к процессам, происходящим в партийной системе. Наиболее высоко проявилась политизированность лиц в возрасте от 18 до 21 года и старше 60 лет, с уровнем жизни выше среднего, жителей Саратова, Энгельса, Вольска и Балашова. С ростом образования наблюдалась тенденция к росту восприимчивости респондентов к деятельности партий, за исключением лиц с послевузовским образованием, что, видимо, вызвано их более высокой критичностью. Наиболее политизированными оказались симпатизанты КПРФ, наименее - сторонники ЛДПР и «СР».

В ответах на вопрос «Что Вы понимаете под термином “национализм"?» (см. табл. 3) большинство респондентов предсказуемо воспроизвели господствующие в России представления о национализме как негативном явлении. Наиболее терпимыми к термину «национализм» оказались люди в возра-

Таблий 1

Какую политическую партию современной России Вы поддерживаете?

\begin{tabular}{|l|c|c|}
\hline \multicolumn{1}{|c|}{ Варианты ответов } & $\begin{array}{c}\text { Количество } \\
\text { ответов }\end{array}$ & Процент \\
\hline «Единая Россия» & 169 & 41,0 \\
\hline «Против всех» & 134 & 32,5 \\
\hline КПРФ & 57 & 13,8 \\
\hline ЛДПР & 15 & 3,6 \\
\hline «Все равно» & 13 & 3,2 \\
\hline «Справедливая Россия» & 7 & 1,7 \\
\hline «РР-ПАРНАС» & 5 & 1,2 \\
\hline ОНФ & 3 & 0,7 \\
\hline «Яблоко» & 2 & 0,5 \\
\hline «Правое дело» & 1 & 0,2 \\
\hline Не указали & 6 & 1,5 \\
\hline
\end{tabular}

Таблииа 2

В какой мере на Ваше мировоззрение и поведение оказывают влияние агитация партий, выступления их лидеров, программные положения?

\begin{tabular}{|l|c|c|}
\hline \multicolumn{1}{|c|}{ Варианты ответов } & $\begin{array}{c}\text { Количество } \\
\text { ответов }\end{array}$ & Процент \\
\hline Не оказывают никакого влияния & 175 & 42,5 \\
\hline Практически не оказывают влияния & 119 & 28,9 \\
\hline Оказывают некоторое влияние & 84 & 20,4 \\
\hline Оказывают значительное влияние & 28 & 6,8 \\
\hline Другое & 5 & 1,1 \\
\hline Не указали & 1 & 0,2 \\
\hline
\end{tabular}

ISSN 1998-9938. Вестн. Волгогр. гос. ун-та. Сер. 4, Ист. 2016. Т. 21. № 2 
сте до 30 лет, прежде всего студенты, что может говорить о повышении позитивного восприятия этого термина у лиц, рожденных после развала СССР. Однако мягкие и позитивные оценки национализма часто встречались и у пенсионеров. Количество позитивных оценок национализма снижалось с падением уровня жизни опрошенных.

Более трети сторонников «Единой России» понимали термин «национализм» в нейтральном или позитивном ключе, около $2 / 3$ - в негативном. При этом крайне редким среди сторонников «ЕР» было восприятие национализма в либеральном духе освобождения народов и национального возрождения. Почти половина сторонников КПРФ понимали «национализм» как нейтральное или позитивное явление, с незначительным перевесом доминировали негативные оценки национализма. Примерно такие же оценки национализма присутствовали среди сторонников «СР», что говорит о несколько больших возможностях для адаптации национальной тематики в дискурсе этих партий по сравнению с «ЕР». Менее ожидаемыми были похожие оценки национа- лизма сторонниками ЛДПР. Еще более неожиданными стали исключительно положительные оценки термина «национализм» среди сторонников непарламентских «Яблока» и «Правого дела». Напротив, у сторонников «РПРПАРНАС» присутствовали почти исключительно негативные оценки национализма, что говорит о неприятии национальной тематики сторонниками партии.

В вопросе «Какие политические партии современной России Вы можете отнести к националистическим?» (табл. 4) можно было выбрать не более 3 вариантов ответа. Относительное большинство опрошенных полагали, что таких партий нет вовсе, но до половины всех ответивших в общей сложности оценивали ведущие политические партии России в качестве националистических. Чаще это были люди среднего достатка, большая часть которых имела высшее образование.

«Единую Россию» к числу националистических партий в большинстве относили: женщины, студенты, респонденты в возрасте от 22 до 25 лет и от 46 до 60 лет, жители Саратова и Балаково. Все они в подавляю-

Что Вы понимаете под термином «национализм»?

Таблица 3

\begin{tabular}{|l|c|c|}
\hline \multicolumn{1}{|c|}{ Варианты ответов } & $\begin{array}{c}\text { Количество } \\
\text { ответов }\end{array}$ & Процент \\
\hline Ненависть к людям иной национальности & 193 & 46,8 \\
\hline $\begin{array}{l}\text { Необходимый для общества и государства инструмент, спла- } \\
\text { чивающий людей }\end{array}$ & 74 & 18,0 \\
\hline То же, что и «патриотизм»- любовь к Родине & 59 & 14,3 \\
\hline Идеология порабощения одних народов другими & 30 & 7,3 \\
\hline Идеология освобождения одних народов от диктата других & 20 & 4,9 \\
\hline Другое & 33 & 8,1 \\
\hline Не указали & 3 & 0,7 \\
\hline
\end{tabular}

Какие политические партии современной России

Таблийа 4 Вы можете отнести к националистическим?

\begin{tabular}{|l|c|c|}
\hline \multicolumn{1}{|c|}{ Варианты ответов } & $\begin{array}{c}\text { Количество } \\
\text { ответов }\end{array}$ & Процент \\
\hline «Нет таких» & 159 & 31,3 \\
\hline ЛДПР & 111 & 21,9 \\
\hline «Единая Россия» & 60 & 11,8 \\
\hline КПРФ & 45 & 8,9 \\
\hline «РПР-ПАРНАС» & 34 & 6,7 \\
\hline «Правое дело» & 25 & 4,9 \\
\hline «Справедливая Россия» & 23 & 4,5 \\
\hline «Яблоко» & 14 & 2,8 \\
\hline Другие & 37 & 7,3 \\
\hline
\end{tabular}


щем большинстве рассматривали национализм в нейтральном или позитивном ключе, что говорит о различиях в восприятии национализма применительно к этой партии между ее сторонниками и прочими гражданами. Неожиданными стоит признать более распространенные оценки «ЕР» в качестве националистической, чем КПРФ. Последнюю к националистической также преимущественно относили лица от 22 до 25 лет и от 46 до 60 лет, чаще студенты и пенсионеры, в основном - жители Саратова и Балашова. Большинство рассматривавших КПРФ в качестве националистической придерживались восприятия национализма как нейтрального или позитивного явления, что более соответствовало восприятию этого термина сторонниками партии. «Справедливую Россию», как и «ЕР», к числу националистических чаще относили женщины, граждане от 18 до 21 года и от 46 до 60 лет, в основном жители Саратова, подавляющее большинство которых рассматривали национализм в нейтральном или позитивном свете. ЛДПР вполне ожидаемо чаще прочих рассматривалась как националистическая. К таковым ее причисляли в основном люди в возрасте от 22 до 25 лет и от 46 до 60 лет, широкого спектра национальностей, чаще - жители Саратова, Пугачева, Вольска, Балаково и Балашова. При этом большинство из них придерживалось негативных оценок национализма, что говорит о переходе партией грани «приемлемости» в вопросе использования национальной тематики. Из отнесших «РПР-ПАРНАС» к числу националистических большинство респондентов было в возрасте от 46 до 60 лет и старше 60 лет, представленное, прежде всего, пенсионера- ми и работниками внебюджетной сферы, которые в основном рассматривали национализм как негативное явление. По данному показателю эта партия опередила «Правое дело», в большей степени ориентированное на националистический электорат. «Правое дело» как националистическую партию чаще рассматривали респонденты в возрасте от 18 до 21 лет и от 46 до 60 лет, как правило, студенты, пенсионеры и работники внебюджетной сферы, незначительное большинство которых негативно оценивало национализм. «Яблоко» в качестве националистической чаще рассматривали люди в возрасте от 46 до 60 лет, с высшим и средним образованием, жители Саратова и Пугачева, подавляющее большинство которых также рассматривало национализм в негативном свете. В силу практически полного отсутствия у «Яблока» и «РПР-ПАРНАС» националистической риторики их неожиданное причисление респондентами к ряду националистических партий можно рассматривать как выражение негативного отношения к данным партиям безотносительно содержания их политических линий и дискурсов.

Большинство ответивших на вопрос «Как Вы относитесь к мигрантам, принадлежащим к иной культуре и исповедующим иную религию?» (табл. 5) выбрали наиболее «нейтральный» вариант ответа. У мужчин присутствовало более негативное отношение к мигрантам, как у лиц старше 60 лет и пенсионеров, лиц со средним образованием, жителей Саратова и в основном русских. Немного более негативное отношение к мигрантам проявили сторонники КПРФ и ЛДПР, более умеренное - сторонники «ЕР» и «СР».

Таблича 5

Как Вы относитесь к мигрантам, принадлежащим к иной культуре и исповедующим иную религию?

\begin{tabular}{|l|c|c|}
\hline \multicolumn{1}{|c|}{ Варианты ответов } & $\begin{array}{l}\text { Количество } \\
\text { ответов }\end{array}$ & Процент \\
\hline $\begin{array}{l}\text { Присутствие мигрантов допустимо в том случае, если } \\
\text { они встраиваются в культуру нашего общества }\end{array}$ & 228 & 55,3 \\
\hline Нейтрально, мигранты мне не мешают & 102 & 24,8 \\
\hline $\begin{array}{l}\text { Негативно, мигранты не нужны, так как создают множе- } \\
\text { ство проблем }\end{array}$ & 70 & 17,0 \\
\hline $\begin{array}{l}\text { Положительно, необходимо поощрять миграцию и по- } \\
\text { вышать терпимость к ней }\end{array}$ & 7 & 1,7 \\
\hline Другое & 5 & 1,0 \\
\hline
\end{tabular}

ISSN 1998-9938. Вестн. Волгогр. гос. ун-та. Сер. 4, Ист. 2016. Т. 21. № 2 
В ответах на вопрос о характеристиках использования партиями «национальной» тематики (табл. 6) женщины почти вдвое чаще мужчин полагали, что партии «повышают накал〉 межнациональных отношений. В основном так же считали люди в возрасте от 22 до 25 лет, с высшим образованием, часто бюджетники. Но большинство лиц с высшим образованием, как студентов и безработных, полагали, что в целом партии стремятся «смягчить» межнациональные отношения, что говорит либо о приемлемом общем уровне национальной тематики в партийном дискурсе, либо неочевидном для граждан характере ее использования.

В ответах на вопрос «Чьи интересы для Вас важнее всего?» (табл. 7) для женщин более важными оказались интересы отдельного человека и мирового сообщества, для мужчин - несколько чаще в сравнении с женщи-

нами - интересы одного народа (нации) и государства. Стоит отметить, что с увеличением возраста респондентов наблюдался рост ценности государства и, в меньшей степени, одного народа. Напротив, чем младше были респонденты, тем выше был приоритет отдельного человека.

В ответах на вопрос «Считаете ли Вы допустимым передел государственных границ в соответствии с настроениями народов?» (табл. 8) мужчины несколько чаще, чем женщины, допускали возможность передела государственных границ при возникшей необходимости. Чаще всего так же полагали лица со средним образованием, респонденты, «ни в чем себе не отказывающие», и, в подавляющем большинстве, только русские. Стоит отметить, что респонденты, считающие, что передел государственных границ недопустим, в устной форме часто поддерживали присое-

Таблица 6

На Ваш взгляд, политические партии современной России в основном...

\begin{tabular}{|l|c|c|}
\hline \multicolumn{1}{|c|}{ Варианты ответов } & $\begin{array}{c}\text { Количество } \\
\text { ответов }\end{array}$ & Процент \\
\hline Стремятся «смягчить» межнациональные отношения & 205 & 49,8 \\
\hline Не затрагивают тематику межнациональных отношений & 102 & 24,8 \\
\hline «Повышают накал» межнациональных отношений & 71 & 17,2 \\
\hline Другое & 31 & 7,1 \\
\hline Не указали & 3 & 0,7 \\
\hline
\end{tabular}

Чьи интересы для Вас важнее всего?

Таблича 7

\begin{tabular}{|l|c|c|}
\hline \multicolumn{1}{|c|}{ Варианты ответов } & $\begin{array}{c}\text { Количество } \\
\text { ответов }\end{array}$ & Процент \\
\hline Отдельного человека/семьи & 241 & 58,5 \\
\hline Конкретного государства & 94 & 22,8 \\
\hline Мирового сообщества & 34 & 8,3 \\
\hline Одного народа (нации) & 32 & 7,8 \\
\hline Другое & 9 & 2,1 \\
\hline Не указали & 2 & 0,5 \\
\hline
\end{tabular}

Таблица 8

\section{Считаете ли Вы допустимым передел государственных границ в соответствии с настроениями народов?}

\begin{tabular}{|l|c|c|}
\hline \multicolumn{1}{|c|}{ Варианты ответов } & $\begin{array}{c}\text { Количество } \\
\text { ответов }\end{array}$ & Процент \\
\hline $\begin{array}{l}\text { Это возможно только в исключительных случаях с взаим- } \\
\text { ного согласия государств и проведения референдума }\end{array}$ & 219 & 53,2 \\
\hline $\begin{array}{l}\text { Нет, территориальная целостность любого государства } \\
\text { священна }\end{array}$ & 135 & 32,8 \\
\hline Да, это допустимо делать при необходимости & 49 & 11,9 \\
\hline Другое & 7 & 1,5 \\
\hline Не указали & 2 & 0,5 \\
\hline
\end{tabular}


динение Крыма к России. Это говорит о непоследовательности и зыбкости позиции респондентов в данном вопросе.

Результаты ответов на вопрос «Принимали ли Вы участие в акциях, митингах, шествиях, демонстрациях, основанных на национальной почве?» (табл. 9) показывают, что мужчины существенно чаще участвовали в них, чем женщины. Наиболее активными участниками подобных акций являлись молодые люди в возрасте от 18 до 21 года (чаще студенты) и лица, старше 60 лет (чаще пенсионеры), с уровнем жизни выше среднего и те, кому «хватает только на самое необходимое», в подавляющем большинстве - русские.

Ответы на вопрос «Готовы ли Вы принять участие в акциях, митингах, шествиях, демонстрациях, основанных на национальной почве?» (табл. 10) показали, что имеет место тенденция к снижению количества участников таких акций, однако потенциальные участники могут актуализироваться при определенных условиях. По-прежнему большинство из потенциально активных участников - мужчины в возрасте от 18 до 21 года и от 22 до 25 лет, студенты и пенсионеры, люди со средним и выше среднего уровнями жизни. Респонденты, «еле сводящие концы с концами», почти не были готовы принимать никакого участия в подобных акциях, что еще раз говорит об игнорировании ими участия в поли- тике. Активное участие были готовы принять только русские, в основном жители Саратова, а также Энгельса, Вольска и Балаково. Жители Пугачева, в котором имели место серьезные межэтнические волнения, не проявили себя как активные сторонники подобных акций, что, возможно, говорит об исчерпанности острой фазы данных конфликтов в городе, либо «усталости» людей от этой темы.

Качествам своего народа/нации подавляющее большинство опрошенных также дали умеренные оценки (см. табл. 11). Женщины значительно чаще, чем мужчины, считали, что их нация/народ превосходит другие, что вступает в противоречие с их более «мягкими» ответами на предыдущие вопросы. Этот же вариант ответа несколько активнее остальных выбирали люди в возрасте от 18 до 21 года (в основном студенты), как и безработные, бюджетники, лица с незаконченным средним и средним образованием, а также жители таких районных центров, как Аткарск, Балашов, Маркс, Пугачев и Ртищево. Напротив, респонденты старше 60 лет немного чаще, чем остальные, полагали, что их нация/народ уступает другим, что, на первый взгляд, противоречит их более активной гражданской позиции и более терпимому отношению к националистическим идеям, однако это может говорить и об оправдании активных действий для преодоления этого «отстающего состоя-

Таблииа 9

Принимали ли Вы участие в акциях, митингах, шествиях, демонстрациях, основанных на национальной почве?

\begin{tabular}{|l|c|c|}
\hline \multicolumn{1}{|c|}{ Варианты ответов } & $\begin{array}{c}\text { Количество } \\
\text { ответов }\end{array}$ & Процент \\
\hline Не принимал(-а) в них участия & 351 & 85,2 \\
\hline Принимал(-а) в них некоторое и нерегулярное участие & 41 & 10,0 \\
\hline Да, принимал(-а) в них активное и регулярное участие & 18 & 4,4 \\
\hline Не указали & 2 & 0,5 \\
\hline
\end{tabular}

Таблица 10

Готовы ли Вы принять участие в акциях, митингах, шествиях, демонстрациях, основанных на национальной почве?

\begin{tabular}{|l|c|c|}
\hline \multicolumn{1}{|c|}{ Варианты ответов } & $\begin{array}{c}\text { Количество } \\
\text { ответов }\end{array}$ & Процент \\
\hline Нет, не готов(-а) принимать в них никакого участия & 291 & 70,6 \\
\hline Не определился(-ась) & 76 & 18,4 \\
\hline Готов(-а) принять в них некоторое участие & 29 & 7,0 \\
\hline Да, готов(-а) принять в них активное участие & 13 & 3,2 \\
\hline Другое & 2 & 0,5 \\
\hline Не указали & 1 & 0,2 \\
\hline
\end{tabular}


ния». Как превосходство своего народа/нации над другими, так и его «ущербность» провозглашали практически только русские, что говорит о двух основаниях для проявлений русского национализма: как в форме шовинизма, так и в форме сплочения нации для преодоления трудностей.

Ответы респондентов на вопрос о вероятности широкого распространения националистических идей в современной России (табл. 12) говорили в пользу существенного роста подобных настроений. Такой точки зрения чаще придерживались женщины, респонденты в возрасте от 26 до 30 лет, госслужащие, предприниматели, безработные, в основном проживающие в Балашове, Балаково, Вольске, Энгельсе, Пугачеве и Саратове.
Результаты ответов на вопрос «Как Вы считаете, существует ли проблема межнациональной розни в Саратовской области?» (табл. 13) показали, что оценки межнациональных отношений в регионе также имеют тенденцию к обострению, однако они менее драматичны, чем оценки ситуации в России, что может говорить о решающей роли СМИ в формировании негативного восприятия происходящих в стране процессов; нежелании респондентов идентифицировать свою жизнь с масштабами страны; наличии укоренившихся стереотипов в массовом сознании. При этом большинство драматически оценивавших ситуацию демонстрировали политическую пассивность, нейтрально относились к мигрантам, не провозглашали превосходства над другими

Таблица 11

Считаете ли Вы, что Ваша нация/народ в целом...

\begin{tabular}{|l|c|c|}
\hline \multicolumn{1}{|c|}{ Варианты ответов } & $\begin{array}{c}\text { Количество } \\
\text { ответов }\end{array}$ & Процент \\
\hline Имеет уникальные особенности & 214 & 51,9 \\
\hline $\begin{array}{l}\text { Не имеет исключительных качеств и не отличается } \\
\text { от других наций/народов }\end{array}$ & 144 & 35,0 \\
\hline Превосходит другие нации/народы & 29 & 7,0 \\
\hline Во многом уступает другим нациям/народам & 21 & 5,1 \\
\hline Другое & 2 & 0,5 \\
\hline Не указали & 2 & 0,5 \\
\hline
\end{tabular}

Таблица 12

На Ваш взгляд, вероятность широкого распространения националистических идей в современной России...

\begin{tabular}{|l|c|c|}
\hline \multicolumn{1}{|c|}{ Варианты ответов } & $\begin{array}{c}\text { Количество } \\
\text { ответов }\end{array}$ & Процент \\
\hline Несколько возросла & 171 & 41,5 \\
\hline Значительно возросла & 129 & 31,3 \\
\hline Не претерпела изменений & 68 & 16,5 \\
\hline Несколько снизилась & 29 & 7,0 \\
\hline Значительно снизилась & 7 & 1,7 \\
\hline Другое & 8 & 1,9 \\
\hline
\end{tabular}

Таблица 13

Как Вы считаете, существует ли проблема межнациональной розни в Саратовской области?

\begin{tabular}{|l|c|c|}
\hline \multicolumn{1}{|c|}{ Варианты ответов } & $\begin{array}{c}\text { Количество } \\
\text { ответов }\end{array}$ & Процент \\
\hline Такая проблема возникает время от времени & 202 & 49,0 \\
\hline Такая проблема существует и обострилась в последнее время & 94 & 22,8 \\
\hline Нет, такой проблемы не существует & 47 & 11,4 \\
\hline $\begin{array}{l}\text { Такая проблема существует, но стала менее острой в послед- } \\
\text { нее время }\end{array}$ & 33 & 8,0 \\
\hline Да, конечно, и она непрерывно обостряется с каждым днем & 32 & 7,8 \\
\hline Не знаю & 4 & 1,0 \\
\hline
\end{tabular}


нациями/народами. Необходимо обратить внимание на более негативные оценки межнациональных отношений в Саратовской области среди самых обеспеченных и самых необеспеченных, в основном русских, жителей Балашова, Энгельса и Саратова.

Анализ данных, полученных при ответе на вопрос «Каких политических взглядов Вы придерживаетесь?» (табл. 14), показал, что в сравнении с количеством граждан, ориентированных на либеральные и социалистические идеи, существует значительный дефицит поддержки либеральных и социал-демократических партий, говорящий о низком уровне доверия к ним и отсутствии их восприятия в качестве политической альтернативы существующему положению вещей. Мужчины активнее выступали в качестве сторонников политических взглядов в целом и консервативных, националистических и коммунистических в частности, женщины чуть чаще придерживались только либеральных взглядов. Люди в возрасте от 18 до 21 года (в основном студенты) охотнее остальных возрастных групп придерживались либеральных и консервативных взглядов, реже прочих - коммунистических и националистических взглядов. В свою очередь, лица старше 60 лет (в основном пенсионеры) были наиболее идеологизированы, реже прочих придерживались либеральных, но чаще других оказывались приверженцами националистических, социалистических и коммунистических взглядов. Также националистических взглядов придерживались респонденты со средним образованием, которым «хватает только на самое необходимое», предприниматели, жители Вольска, Пугачева и русские.

Большинство респондентов, поддерживающих «СР», придерживались социалистичес- ких и коммунистических взглядов, что говорит о соответствии между идеологическим позиционированием партии и ее электоратом. Остальные парламентские партии поддерживали люди с достаточно пестрым идеологическим составом. Почти каждый второй сторонник «ЕР» не имел определенных взглядов, что может объясняться фактическим отсутствием партийной идеологии. Но при этом в поддержку «ЕР» также выступало наибольшее число опрошенных, придерживающихся либеральных и социалистических взглядов, что может объясняться отсутствием альтернативного представительства их интересов, поддержкой партии исходя из восприятия ее как наиболее значимой в российской политической системе, а также эксплуатацией «ЕР» разнородных дискурсов и идеологем. Это же говорит о больших возможностях партии к абсорбции «чужих» электоратов. КПРФ среди парламентских партий обладала наименьшим числом сторонников без политических взглядов, а идейная ориентация их большинства совпадала с декларируемой идеологией партии. Среди сторонников ЛДПР $40 \%$ не имели определенных взглядов, значительное количество занимали либералы и коммунисты, что может объясняться несоответствием между названием партии, ее риторикой и проводимой политикой. Большинство же сторонников националистических идей вообще не видели сил, представляющих их интересы. Почти половина приверженцев консервативных взглядов также выступила «против всех», проигнорировав формальную приверженность «ЕР» и ЛДПР консерватизму, как и примерно четверть от всех либералов.

Из 241 респондента, отдающего приоритет интересам отдельного человека, только 44

Каких политических взглядов Вы придерживаетесь?

\begin{tabular}{|l|c|c|}
\hline \multicolumn{1}{|c|}{ Варианты ответа } & $\begin{array}{c}\text { Количество } \\
\text { ответов }\end{array}$ & Процент \\
\hline Не придерживаюсь определенных взглядов & 192 & 46,6 \\
\hline Социалистических & 64 & 15,5 \\
\hline Либеральных & 58 & 14,1 \\
\hline Коммунистических & 46 & 11,2 \\
\hline Консервативных & 34 & 8,3 \\
\hline Националистических & 8 & 1,9 \\
\hline Другое & 6 & 1,3 \\
\hline Не указали & 4 & 1,0 \\
\hline
\end{tabular}


были сторонниками либеральных взглядов, кроме них присутствовало большое число приверженцев социалистических и коммунистических взглядов, а 119 вообще не придерживались каких-либо взглядов, что говорит об отсутствии идеологических оснований у данного индивидуализма и элементарном стремлении людей к выживанию. Однако при определенных обстоятельствах атомизированность общества может быть трансформирована как в сторону принятия либеральных ценностей (прежде всего молодым поколением), так и в сторону дальнейшего усиления государства, либо в направлении традиционализма и сплочении людей перед лицом внешнего врага.

Лица, придерживающиеся националистических взглядов, примерно поровну распределились между приоритетом интересов отдельного человека и государства, причем среди них присутствовал только один сторонник приоритета интересов одной нации/народа, что, вероятно, говорит о низкой ценности этнического фактора в российском политическом пространстве. Ожидаемо большая часть сторонников националистических взглядов негативно относилась к присутствию мигрантов, менее половины выступали за их встраивание в культуру принявшего общества. Примерно таких же оценок придерживались социалисты и коммунисты. Из меньшинства, считающего, что миграцию нужно поощрять, чаще остальных были люди, не придерживающиеся определенных взглядов, и либералы. Кроме того, сторонники националистических и либеральных взглядов чаще других полагали, что их нация/народ превосходит другие нации/народы.

Стоит отметить, что передел государственных границ при возникшей необходимос- ти считали допустимым более половины от всех опрошенных националистов. Наряду с этим, респонденты с националистическими взглядами не принимали активного участия в акциях на национальной почве, как и почти не принимали участия в подобных акциях лица без определенных политических взглядов, в отличие от коммунистов, либералов и социалистов. Некоторое и нерегулярное участие принимала лишь треть от всех опрошенных националистов. Несмотря на снижение количества потенциального актива подобных акций, возросла пестрота их возможного идеологического состава. Среди возможных неактивных участников подобных акций отсутствовали представители националистов.

Полагали, что имеет место значительное возрастание распространения националистических идей в стране, прежде всего, либералы и националисты. Наиболее драматичные оценки межнациональных отношений в Саратовской области закономерно давали приверженцы националистических взглядов, а также социалисты, коммунисты и либералы. Активный интерес к таким акциям со стороны коммунистов, социалистов и либералов позволяет говорить о первичных требованиях улучшения материального положения и соблюдения прав и свобод граждан как путей для снижения межнациональной напряженности.

При ответе на вопрос «На Ваш взгляд, какие политические партии современной России имеют наибольшее влияние на политическую ситуацию в стране?» (табл. 15) респондентам можно было выбрать не более трех вариантов. Стоит подчеркнуть, что непарламентские партии не рассматривались в качестве полноценных участников политического

На Ваш взгляд, какие политические партии современной России имеют наибольшее влияние на политическую ситуацию в стране?

\begin{tabular}{|l|c|r|}
\hline \multicolumn{1}{|c|}{ Варианты ответов } & $\begin{array}{c}\text { Количество } \\
\text { ответов }\end{array}$ & Процент \\
\hline «Единая Россия» & 374 & 52,6 \\
\hline КПРФ & 156 & 22 \\
\hline ЛДПР & 93 & 13,1 \\
\hline «Пправедливая Россия» & 62 & 8,7 \\
\hline «Правое дело» & 4 & 0,6 \\
\hline «РПР-ПАРНАС» & 3 & 0,4 \\
\hline «Яблоко» & 2 & 0,3 \\
\hline Другое & 17 & 2,3 \\
\hline
\end{tabular}


процесса, уровень их поддержки колебался в рамках статистической погрешности. Одной из самых влиятельных партий большинством респондентов предсказуемо воспринималась «Единая Россия», причем женщины немного чаще признавали ее в качестве таковой. «ЕР» также чаще набирала «очки влияния» со стороны респондентов с высоким уровнем жизни, что говорит о связи между благосостоянием граждан и их ориентацией на действующую власть. КПРФ несколько чаще относилась к наиболее влиятельным партиям мужчинами, в основном жителями Саратова, Ртищево, Маркса, Красного Кута, Вольска, Балаково, Энгельса, и пользовалась признанием в качестве одной из ведущих политических партий страны вне зависимости от уровня жизни респондентов. Реже всего в качестве одной из наиболее влиятельных партий ее признавали предприниматели. Важно отметить, что «Справедливая Россия» достаточно редко рассматривалась респондентами как одна из самых влиятельных партий, несмотря на ее третье место в Государственной Думе по числу мандатов, что, вероятно, говорит о перспективах потери партией части своих депутатских кресел по итогам грядущих выборов в Государственную Думу. Эту партию к числу наиболее влиятельных чаще относили женщины и безработные, жители Энгельса и Вольска, реже других - военнослужащие и, что примечательно, люди, «еле сводящие концы с концами». В целом со снижением уровня жизни снижалось и количество респондентов, воспринимавших данную партию как одну из наиболее влиятельных, что, несомненно, противоречит позиционированию партии себя в качестве защитницы социально незащищенных слоев населения. Это может говорить и о недостаточно активной политике «СР», и о разочаровании в ней избирателей, актуализации повестки дня, более характерной для дискурса ЛДПР. Последнюю мужчины и женщины почти поровну отнесли к наиболее влиятельным партиям страны. Чаще она рассматривалась как одна из наиболее влиятельных партий в таких районных центрах, как Балаково, Ртищево, Вольск, Энгельс и Аткарск. Наименьшее значение отвели партии предприниматели и лица, которые «ни в чем себе не отказывают», что позволяет говорить об от- сутствии к ней интереса со стороны состоятельных людей.

В целом можно констатировать, что у большинства респондентов наблюдалось отсутствие целостной картины политики и системных взглядов на нее и, соответственно, доминирование эмоционального восприятия данной сферы. Материалы опроса подтвердили отсутствие осознанной мотивации политического участия российских граждан в политике и невысокий уровень их практической вовлеченности в политический процесс.

Опрос показал, что не существует прямых зависимостей между декларируемыми политико-идеологическими взглядами россиян и их реальным содержанием. Это свидетельствует не только о противоречивости и фрагментарности массовой политической культуры, но и о размывании идеологических границ и соответствующих идентификационных маркеров современной России. Данное обстоятельство подтверждает приоритет дискурсивного фактора в политической и ценностной самоидентификации граждан по сравнению с идеологическим и партийным факторами (например, опрошенный мог заявить о себе как стороннике ЛДПР, оценивать ее националистической партией и при этом рассматривать национализм как негативное явление).

Проведенный анализ позволяет утверждать, что в массовом сознании российских граждан проявляется двоякое толкование национализма. С одной стороны, у большинства населения доминирует традиционное его понимание как негативного и опасного явления, связанного с обоснованием превосходства одного этноса/нации над другими. Фактически национализм чаще всего воспринимается как синоним ксенофобии. С другой стороны, можно говорить о наличии определенных тенденций укрепления государственного (имперского) национализма в сознании россиян. Объяснить этот дуализм можно традиционно высокой значимостью ценности державности в политической культуре россиян, а также обострением международных отношений в связи с украинским кризисом и активной позицией России в борьбе против ИГИЛ. В этих условиях государственный национализм представляет собой один из элементов патриотизма, который актуализирует его мобилизационную 
и интегрирующую функциональность для всего российского населения независимо от этнической принадлежности (по линии противостояния «мы Россия - они Запад»).

Внутренние этнонационалистические, ксенофобные настроения также проявляются в сознании граждан, однако можно отметить тенденцию их снижения перед лицом внешних вызовов и угроз. Происходит постепенная маргинализация данных настроений в политическом пространстве страны. Однако данное смещение не означает осознанное укоренение ценностей толерантности в политической культуре тех россиян, которые склонны к ксенофобии. Оно представляет собой скорее ситуативное перенесение своего неприятия «другого» на внешнюю среду.

Все парламентские партии России в той или иной степени ориентировались на актуализацию ностальгических оснований державного национализма, хотя и в контексте своих специфических партийно-идеологических ориентиров. Тем самым каждая из них способствует дальнейшему укоренению подобных идей в сознании общества. Кроме того, ЛДПР - единственная из ведущих политических партий, которая позволяет себе определенную апелляцию к этнонационалистическим настроениям русского населения. Фактически происходит канализация потенциально опасных националистических проявлений в правовое русло на основе их политического представительства в парламенте. До сих пор партии В.В. Жириновского удавалось играть роль своеобразного «выхлопного клапана» для управляемого «выброса» негативных эмоций части российского населения, недовольного последствиями миграционных процессов и другими проблемами межэтнических отношений. Однако такой политический механизм не устраняет сами противоречия и проблемы межэтнических отношений, которые нуждаются в очень взвешенной, последовательной и повсеместной работе государственных органов на всех уровнях во взаимодействии с системой политической социализации и разнообразными институтами гражданского общества в современной России.

\section{СПИСОК ЛИТЕРАТУРЫ}

1. Гроздья гнева: рейтинг межэтнической напряженности в регионах России. Осень 2013 - весна 2014. - Электрон. текстовые дан. - Режим доступа: http://club-rf.ru/thegrapesofwrath/01/ (дата обращения: 04.01.2015). - Загл. с экрана.

2. Мосина, В. В. Этническая политика как инструмент предотвращения межэтнической напряженности и конфликтов в регионе / В. В. Мосина // Известия Саратовского университета. Серия: Социология. Политология. - 2012. - Т. 12, вып. 3. C. 54-57.

\section{REFERENCES}

1. Grozdya gneva: reyting mezhetnicheskoy napryazhennosti v regionakh Rossii. Osen 2013 vesna 2014 [The Grapes of Wrath: Rating of Ethnic Tensions in Russian Regions. Autumn 2013 - Spring 2014]. Available at: http://club-rf.ru/thegrapesofwrath/ 01/. (accessed January 4, 2015).

2. Mosina V.V. Etnicheskaya politika kak instrument predotvrashcheniya mezhetnicheskoy napryazhennosti i konfliktov v regione [Ethnic Policy as an Instrument to Prevent Inter-Ethnic Tensions and Conflicts in the Region]. Izvestiya Saratovskogo Universiteta. Seriya: Sotsiologiya. Politologiya, 2012, vol. 12, iss. 3, pp. 54-57. 